\title{
ETHNIC VARIATION IN INTERLEUKIN-6 -174 (G/C) POLYMORPHISM IN THE MALAYSIAN POPULATION
}

\author{
Gan G-G*, Subramaniam R, Lian L-H, Nadarajan VS
}

\begin{abstract}
*Corresponding Author: Professor Dr. Gin-Gin Gan, Department of Medicine, Faculty of Medicine, University Malaya, Lembah Pantai, Kuala Lumpur, Malaysia; Tel.: +603-79-492-429; Fax: +603-79-556-936; E-mail: gangg@ummc.edu.my
\end{abstract}

\section{ABSTRACT}

Interleukin-6 (IL-6) is one of the cytokines that has been well studied and implicated in many diseases including cancers. The frequency of the IL-6 $-174(\mathrm{G} / \mathrm{C})$ polymorphism had been proven to differ in various populations. Malaysia is a country with three major ethnic populations, Malays, Chinese and Indians. In this study, we proposed to determine the $\mathrm{G}$ or C allele frequency of the IL-6-174 polymorphism in these three populations. A total of 348 blood samples were available for analysis. The median age for the subjects was 31 years. There were a total of 245 males and 103 females. A total of 86 Malays (25.0\%), 122 Chinese (33.0\%) and 140 Indians (40.0\%) were genotyped. The result showed a significant difference in the $\mathrm{G}$ or $\mathrm{C}$ allele frequency of the -174 polymorphism. The total frequencies for the $\mathrm{G}$ and $\mathrm{C}$ alleles were 91.0 and $9.0 \%$, respectively. In the Malays, the allele frequency of the $\mathrm{C}$ allele was $4.0 \%$ compared with $19.0 \%$ in the Indians. The $\mathrm{C}$ allele was not detected in the Chinese population. This finding is the first reported on the Malaysian population and may be important in determining risk of diseases associated with the IL-6 polymorphism in these three populations.

Keywords: Interleukin-6 (IL-6) polymorphism; Genetic; Ethnic differences in Asia

Department of Medicine, Faculty of Medicine, University Malaya, Kuala Lumpur, Malaysia

\section{INTRODUCTION}

Interleukin-6 (IL-6) is a pleiotropic inflammatory cytokine that has been implicated in the development of Alzheimer's disease, cardiovascular diseases and many different types of cancers [1-5]. The role of IL-6 in mediating humoral and cellular immune response relating to inflammation and tissue injury has been well established [6]. Several studies have demonstrated that elevated IL-6 level is associated with vascular smooth muscle growth and increased production of acute phase protein, thereby contributing to possible development of cardiovascular disease as well as Alzheimer's disease [3,5,7,8].

The IL-6 $-174 \mathrm{G}$ allele had been demonstrated to be associated with higher IL-6 production [7]. This polymorphism affects the circulating serum IL-6 level and IL- 6 gene transcription. There have been extensive studies on IL-6 gene polymorphisms in different diseases and interestingly, there is also significant variation in the frequencies of this polymorphism among different ethnic groups. It was reported that frequency of the $-174 \mathrm{C}$ allele is much lower in the Japanese, Africans and Asian Indians compared to European Caucasians [9-12]. It appears that the majority of Asian populations carry the GG genotypes, ranging from $75.0-100.0 \%$, while Caucasians in the West had a higher frequency of CC genotypes, ranging from 18.0$32.0 \%$ [7,9,10,13-15]. Within the Chinese communities in China, there is also a difference in IL-6 allele frequency. A recent study of the Chinese Han population found that $99.57 \%$ carried the GG genotype and none were found to carry the CC genotype [16]. 
Malaysia is a multiethnic country where the three major ethnic groups are Malays, Chinese and Indians. The Malays are the major population group (70.0\%) and are made up of a mixture of people extant in Southeast Asia as early as 3000 years ago [17]. The Chinese account for about $20.0 \%$ of the total population of Malaysia and majority originating from Southern China; the Indians account for about $10.0 \%$ of the total population and were mainly immigrants from Southern India. There have not been any published reports on the IL-6 polymorphism in the Malay or the local Indian populations. A study published by Chua et al. [18] in Malaysia which studied the gene frequency of IL-6 in systemic lupus erythematosus (SLE) patients found that the homozygous G genotype was significantly higher in SLE patients compared with healthy control subjects [18]. However, there was no racial breakdown of these subjects.

In view of the functional implications of the IL-6 gene, we proposed to study the prevalence of the IL-6 -174 (G/C) polymorphism in the Malaysian population. We hope these results can be used as a reference for further studies in determining the disease risk including coronary artery disease among these groups of patients.

\section{MATERIALS AND METHODS}

Subjects. Blood was obtained from healthy blood donors residing in Kuala Lumpur, capital city of Malaysia. The study was approved by the local institution ethics committee and informed consent was obtained from all individuals. DNA was extracted from the blood samples by a standard phenolchloroform method and QiAmp DNA Blood Mini Kit (Qiagen GmbH, Hilden Germany). DNA concentration was measured using an ND-1000 spectrophotometer (Nanodrop Technologies, Wilmington, DE, USA) to assess the quantity of the product.
Cytokine Gene Polymorphism Gene Analyses. The $-174(\mathrm{G} / \mathrm{C})(\mathrm{rs} 1800795)$ polymorphism in the 5' regulatory region of the IL- 6 gene was performed by a custom TaqMan ${ }^{\circledR}$ single nucleotide polymorphism (SNP) genotyping assay (Applied Biosystems, Foster City, CA, USA) system on the LightCycler ${ }^{\circledR} 480$ Real-Time polymerase chain reaction (PCR) 384 well plate system (Roche Applied Science, Mannheim, Germany). It discriminates the (SNP) by detecting differences in the melting temperatures of the products $(T \mathrm{~m})$. The forward primer was 5'-CGA CCT AAG CTG CAC TTT TCC-3' and reverse primer was 5'-GGG CTG ATT GGA AAC CTT ATT AAG ATT G-3'; the probes for the $-174 \mathrm{C}$ allele was 5'CCT TTA GCA TGG CAA GAC-3' and the -174G allele was 5'-CCT TTA GCA TCG CAA GAC-3'. The 5' nuclease assay was performed using 10 to 30 ng genomic DNA, 2X TaqMan ${ }^{\circledR}$ GTXpress ${ }^{\mathrm{TM}}$ Master Mix (Applied Biosystems), and 20X TaqMan ${ }^{\circledR}$ genotyping assay. The PCR cycle consisted of hold for $10 \mathrm{~min}$. at $95^{\circ} \mathrm{C}, 40$ cycles of denaturing for 15 seconds at $92{ }^{\circ} \mathrm{C}$ and annealing for $1 \mathrm{~min}$. at $60^{\circ} \mathrm{C}$. Negative, non template controls and known positive controls were included in each experimental run.

Statistical Analyses. Allele and genotype frequencies of the three ethnic groups were compared using the $\chi^{2}$ contingency table. The data were tested for Hardy-Weinberg equilibrium. A $p$ value of $<0.05$ was considered as statistically significant. All statistical tests were performed using the Statistical Package for the Social Sciences (SPSS) version 17 (SPSS Inc., Chicago, IL, USA).

\section{RESULTS}

A total of 348 blood samples were available for analysis. The median age for the subjects was 31 years (ranges from18-62 years). There were a total of 245 males and 103 females. The sample characteristics are shown in Table 1. Among the 348

Table 1. Baseline characteristic of all samples.

\begin{tabular}{|l|c|c|c|c|c|}
\hline Race & $\boldsymbol{n}$ & Median Age in Years & Range & Males & Females \\
\hline Malay & 86 & 31.0 & $18-51$ & 63 & 23 \\
\hline Chinese & 122 & 31.0 & $18-44$ & 84 & 38 \\
\hline Indians & 140 & 32.5 & $18-60$ & 98 & 42 \\
\hline Total & 348 & 31.0 & $18-60$ & 245 & 103 \\
\hline
\end{tabular}


Table 2. Genotype and allele frequency of IL-6 -174 (G/C) in Malaysian populations.

\begin{tabular}{|c|c|c|c|c|c|c|c|}
\hline & \multicolumn{3}{|c|}{$\begin{array}{c}\text { Genotype Frequencies } \\
n(\%)\end{array}$} & & \multicolumn{2}{|c|}{$\begin{array}{c}\text { Allele Frequencies } \\
n(\%)\end{array}$} & \multirow[b]{2}{*}{$p$ Value } \\
\hline & GG & $\mathrm{GC}$ & $\mathrm{CC}$ & $p$ Value & G & $\mathrm{C}$ & \\
\hline Malay & $80(93.0)$ & $6(7.0)$ & $0(0.0)$ & \multirow{4}{*}{$<0.005$} & $166(96.0)$ & $6(4.0)$ & \multirow{4}{*}{$<0.005$} \\
\hline Chinese & $122(100.0)$ & $0(0.0)$ & $0(0.0)$ & & $244(100.0)$ & $0(0.0)$ & \\
\hline Indians & $92(66.0)$ & $42(30.0)$ & $6(4.0)$ & & $226(81.0)$ & $54(19.0)$ & \\
\hline Total & $294(84.0)$ & $48(14.0)$ & $6(2.0)$ & & $636(91.0)$ & $60(9.0)$ & \\
\hline
\end{tabular}

samples studied, $85.0 \%$ carried the GG wild type $(-174 \mathrm{G} / \mathrm{C}), 14.0 \%$ carried the GC genotype and only $2.0 \%$ carried the CC genotype. The GG genotypes were observed in $100.0 \%$ Chinese, $93.0 \%$ Malays and $66.0 \%$ Indians. The CC genotype was absent in both Chinese and Malay individuals and $4.0 \%$ of individuals of Indian descent carried the CC genotype (Table 2). These differences were statistically significant between the three races $(p<0.01)$.

The total allele frequencies for the $\mathrm{G}$ and $\mathrm{C}$ alleles were 91.0 and $9.0 \%$, respectively. Among the Malays, the allele frequency of the $\mathrm{C}$ allele was $4.0 \%$ compared to $19.0 \%$ in the Indians. Table 2 shows the distribution of the IL-6 -174 (G/C) genotype and allele frequencies in the three different ethnic populations. The genotype distribution among these populations was in Hardy-Weinberg equilibrium.

\section{DISCUSSION}

Cytokine gene polymorphism has been demonstrated in many articles resulting in interindividual variation of transcriptional regulation and subsequently different serum level of cytokines. It has been well established that frequency of the different cytokine gene allele varies among the different populations. The frequency of the IL- 6 gene polymorphism had also been extensively studied in different populations. Ethnic differences were well demonstrated among all major populations. It has been reported that $-174 \mathrm{C}$ allele was completely absent in Japanese and significantly lower in Koreans and Chinese compared with Caucasians $[7,16,19,20]$. Similar findings have also been demonstrated in Africans and the remaining Eastern Asian populations [9,10,11-13,15,16,21-23] (Table 3). It is also interesting to note the absence of the homozygous
C genotype among the Chinese, Korean and African populations $[9,16,19,22,23]$.

In this study, the allele frequency of $-174 \mathrm{C}$ was only $9.0 \%$, much lower than those reported in the European population $[10,13] ; 85.0 \%$ of the subjects carried the GG genotypes and only $2.0 \%$ carried the $\mathrm{CC}$ genotype. However, there were significant differences in the distribution of IL-6 -174 (G/C) between the three ethnic groups. There was a complete absence of the $-174 \mathrm{C}$ polymorphism in the Chinese subjects, which is similar to that reported in the Singapore Chinese populations [9]. This is of no surprise as Malaysian Chinese and Singapore Chinese are very closely related due to geographical and historical reasons.

In contrast, the $\mathrm{C}$ allele frequency was significantly higher $(19.0 \%)$ in the Indians in this study compared with the other two ethnic groups. The IL-6 - 174 (G/C) polymorphism was relatively more evenly distributed in Indians: $66.0 \%$ carried the GG genotype, $30.0 \%$ carried the GC genotype and $4.0 \%$ carried the CC genotype. Study of Indian populations in India had demonstrated the difference in the IL-6 -174 (G/C) polymorphism among the North and South Indians $[11,24]$. There was a higher frequency of the $\mathrm{C}$ allele in North Indians compared to South Indians, 32.4 vs. 15.5\%, respectively. The majority of the South Indians studied (72.0\%) carried the GG genotype and only $2.9 \%$ carried the CC genotype [24]. Our study reported similar findings with the South Indian rather than the North Indian populations. The most likely reason could be due to the fact that most of the Indians in Malaysia were of South Indian ancestry.

The $-174 \mathrm{C}$ allele was only detected in $4.0 \%$ of Malays. There had not been any reports on the frequency of IL-6 -174 (G/C) polymorphism in the Ma- 
Table 3. Genotype and allele frequencies of IL-6 -174 (G/C) in different populations

\begin{tabular}{|l|c|c|c|c|c|c|c|}
\hline Population & References & Number & \multicolumn{3}{|c|}{ Genotypes (\%) } & \multicolumn{2}{c|}{ Alleles (\%) } \\
\hline & & Investigated & GG & GC & CC & G & C \\
\hline Italian Caucasians & 10 & 362 & 49.7 & 39.3 & 11.0 & 71.0 & 29.0 \\
\hline UK Caucasians & 15 & 240 & 31.7 & 52.5 & 15.8 & n.d. & n.d. \\
\hline Brazilians & 21 & 214 & 49.3 & 40.8 & 9.9 & 69.7 & 30.3 \\
\hline Finnish & 13 & 1334 & 19.3 & 51.3 & 29.3 & 55.0 & 45.0 \\
\hline Japanese & 12 & 311 & 100.0 & 0.0 & 0.0 & 100.0 & 0.0 \\
\hline Koreans & 23 & 311 & 100.0 & 0.0 & 0.0 & 100.0 & 0.0 \\
\hline Chinese Han & 16 & 232 & 99.6 & 0.4 & 0.0 & 99.7 & 0.3 \\
\hline North Indians & 11 & 343 & 50.1 & 35.0 & 14.9 & 67.6 & 32.4 \\
\hline South Indians & 24 & 210 & 71.9 & 25.2 & 2.9 & 84.5 & 15.5 \\
\hline Omani & 9 & 80 & 76.2 & 22.5 & 1.3 & 87.5 & 12.5 \\
\hline Africans & 9 & 86 & 98.8 & 1.2 & 0.0 & 99.4 & 0.6 \\
\hline Malaysian Chinese & this study & 122 & 100.0 & 0.0 & 0.0 & 100.0 & 0.0 \\
\hline Malaysian Malays & this study & 86 & 93.0 & 7.0 & 0.0 & 96.0 & 4.0 \\
\hline Malaysian Indians & this study & 140 & 66.0 & 30.0 & 4.0 & 81.0 & 19.0 \\
\hline
\end{tabular}

n.d.: not determined.

lay population and hence this will be the first report. Interleukin- 6 has been extensively studied and has been implicated in many diseases, including coronary artery disease, cancers and Alzheimer's disease. In a meta-analysis reported by Liu et al. [25], the IL-6 $-174(\mathrm{G} / \mathrm{C})$ polymorphism was associated with cancer risk in African populations but not in Caucasian population. Similar meta-analysis by Xu et al. [26] had also demonstrated that there was a possible association of the IL-6 -174 (G/C) polymorphism with cancer risk among Asians and Africans.

A recent meta-analysis of 20 studies suggests that the IL-6 -174 (G/C) polymorphism was associated with increased risk of coronary heart disease among Asians [27]. In the subgroup analysis, it was suggested that individuals with the $\mathrm{C}$ allele might have a higher risk of coronary heart disease. Interestingly, studies involving Asian populations had demonstrated that Asian Indians were at greater risk of coronary heart disease compared to other ethnic populations $[28,29]$. After adjusting for the other risk factors of coronary artery disease, the Indian population remained one of the risk factors [30]. Hence, it is of interest that a higher frequency of the $\mathrm{C}$ allele was found in Indians in this study cohort.
Therefore, this study serves as an important reference study for the Malaysian population and also to provide data for the least studied populations, e.g., Malays and Indians. The result of this study can be used as a reference point for future studies in determining risk factors and association of the mentioned diseases in the Malaysian population.

Declaration of Interest: This study was funded by the University Malaya Research Grant RG307/11HTM. The authors report no conflicts of interest. The authors alone are responsible for the content and writing of this article.

\section{REFERENCES}

1. Hong DS, Angelo LS, Kurzrock R. Interleukin-6 and its receptor in cancer: implication for translational therapeutic. Cancer. 2007; 110(9): 1911-1928.

2. Chung YC, Chaen YL, Hsu CP. Clinical significance of tissue expression of interleukin- 6 in colorectal carcinoma. Anti-Cancer Res. 2006; 26(5B): 3905-1911. 
3. Jenny NS, Tracy RP, Ogg MS, Lung Le A, Kuller LH, et al. In the elderly, interleukin-6 plasma levels and the $-174 \mathrm{G}>\mathrm{C}$ polymorphisms are associated with the development of cardiovascular disease. Arterioscler Thromb Vasc Biol. 2002; 22(12): 2066-2071.

4. Gangwar R, Mittal B, Mittal RD. Association with interleukin-6 $-174 \mathrm{G}>\mathrm{C}$ promoter polymorphism with risk of cervical cancer. Int $\mathrm{J}$ Biol Marker. 2009; 24(1): 11-16.

5. Pola R, Flex A, Gaetani E, Lago AD, Geradino L, Pola $\mathrm{P}$, et al. The -174 polymorphism of the interleukin-6 gene is associated with Alzheimer's disease in an Italian population. Neuroreport. 2002; 13(13): 1645-1647.

6. Kishimoto T. Interleukin-6: from basic science to medicine -40 years in immunology. Annu Rev Immunol. 2005; 23: 1-21.

7. Fishman D, Faulds G, Jeffery R, Mohamed-Ali $\mathrm{V}$, Yudkin JS, Humphries S, et al. The effect of novel poly-morphisms in the interleukin-6 (IL6) gene on IL-6 transcription and plasma IL-6 levels and an association with systemic-onset juvenile chronic arthritis. J Clin Invest. 1998; 102(7): 1369-1376.

8. Ikeda U, Ikeda M, Oohara T, Ooguchi A, Kamitani T, Tsuruya Y, et al. Interleukin-6 stimulates growth of vascular smooth muscle in a PDGFdependent manner. Am J Physiol. 1991; 260(5 Pt 2): H1713-H1717.

9. Meenagh A, Fionnuala W, Owen AR, Patterson C, Gorodezsky C, Hammond M, et al. Frequency of cytokine polymorphism in populations from Western Europe, Africa, Asia, the Middle East and South America. Hum Immunol. 2002; 63(11): 1055-1061.

10. Poli F, Nocco A, Berra S, Scalamogna M, Taioli $\mathrm{E}$, Longhi E, et al. Allele frequencies of TNF- $\alpha$, IL-6, IL-10 and IFN- $\gamma$ in an Italian Caucasian population. Eur J Immunogenet. 2002; 29(3): 237-240.

11. Kesarwani P, Ahirwar D, Singh R, Manchanda PL, Mittal RD. Do IL-4 intron 3 VNTR and IL-6 (-174) G/C variants reflect ethnic variation? A comparative study between the global and North Indian populations. Asian Pac J Cancer Prev. 2008; 9(1):76-80.
12. Ognjanovic S, Yamamoto J, Saltzman B, Franke A, Ognjanovic M, Yokochi L, et al. Serum CRP and IL-6, genetic variants and colorectal adenoma in a multiethnic population. Cancer Causes Control. 2010; 21(7): 1131-1138.

13. Riikola A, Sipilä K, Kähonen M, Jula A, Nieminen MS, Moilanen L, et al. Interleukin-6 promoter polymorphism and cardiovascular risk factors: the Health Survey 2000. Atherosclerosis. 2007; 207(2): 466-470.

14. Capurso C, Solfrizzi V, D'Introno A, Colacicco AM, Capurso SA, Capurso A, et al. Interleukin- $6-174 \mathrm{G} / \mathrm{C}$ promoter gene polymorphism and sporadic Alzheimer disease: geographic allele and genotypic variation in Europe. Exp Gerontol. 2004; 39(10): 1567-1573.

15. Donn RP, Barret JH, Farhan A, Stopford A, Pepper L, Shelley E, et al. Cytokine gene polymorphisms and susceptibility to juvenile idiopathic arthritis. British Paediatric Rheumatology Study Group. Arthritis Rheum. 2001; 44(4): 802-810.

16. Pan M, Gao SP, Jiang MH, Gua J, Zheng JG, Zhu JH. Interluekin-6 promoter polymorphism in normal Han Chinese population: frequency and effects on inflammatory markers. J Invest Med. 2011;59(2):272-276.

17. Hirschman C. The meaning and measurement of ethnicity in Malaysia: an analysis of census classification. J Asian Stud. 1987; 46(3): 555582.

18. Chua KH, Kee BP, Tan SY, Lian LH. Interleukin-6 promoter polymorphisms $(-174 \mathrm{G} / \mathrm{C})$ in Malaysian patients with systemic lupus erythematosus. Braz J Med Biol Res. 2009; 42(6): 551-555.

19. Tong Y, Lu Z, Zhang Y, Ye J, Zhan F, Hou S, et al. Comparison of the $\mathrm{G}-174 \mathrm{C}$ polymorphism of interleu-kin (IL)-6 in different countries. African J Biotechnol. 2012; 11(28): 7166-769.

20. Park BL, Lee HS, Kim YJ, Kim JY, Jung JH, $\mathrm{Kim} \mathrm{LH}$, et al. Association between interleukin 6 promoter variation and chronic hepatitis $\mathrm{B}$ progression. Exp Mol Med. 2003; 35(2): 76-82.

21. Visentainer JEL, Sell AM, da Silva GC, Cavichioli ADG, Franceschi DSA, Liebert SR, et al. TNF, IFNG, IL-6, IL-10 and TGFB1 gene 
polymorphisms in South and Southeast Brazil. Int J Immunogenet. 2008; 35(4-5): 287-293.

22. Ryu JH, Kim SJ. Interleukin- $6-634 \mathrm{C} / \mathrm{G}$ and $-174 \mathrm{G} / \mathrm{C}$ polymorphisms in Korean patients undergoing hemodialysis. Korean $\mathrm{J}$ Int Med. 2012; 27(3): 327-337.

23. Pyo CW, Hur SS, Kim YK, Choi HB, Hong YS, Kim DW, et al. Polymorphism of IL-1B, IL-1 RN, IL-2, IL-4, IL-6, IL-10 and IFN- $\gamma$ genes in the Korean population. Hum Immunol. 2003; 64(10): 979-989.

24. Bhanoori M, Babu KA, Deenadayal M, Kennedy S, Shivaji S.. The interleukin-6 -174G/C promoter polymorphism is not associated with endometriosis in South Indian women. J Soc Gynecol Investig. 2005; 12(5): 365-369.

25. Liu RY, Song X, Chen P, Lei Z, Miao J, Yi N, et al. Association between IL $6-174 \mathrm{G} / \mathrm{C}$ and cancer; a meta-analysis of 105,482 individuals. Exp Ther Med. 2012; 3(4): 655-664.

26. Xu B, Niu XB, Wang ZD, Cheng W, Tong N, Mi YY, et al. IL-6-174G $>$ C polymorphism and cancer risk: a meta-analysis involving 29,377 cases and 37,739 controls. Mol Bio. Rep. 2011; 38(4): 2589-2596.
27. Yin YW, Hu AM, Sun QQ, Liu HL, Wong Q, Zeng $\mathrm{YH}$, et al. Associations between IL-6 gene $-174 \mathrm{G} / \mathrm{C}$ polymorphism and the risk of coronary heart disease; a meta-analysis of 20 studies including 9619 cases and 10,919 controls. Gene. 2012; 53(1): 25-30.

28. Lee J, Heng D, Chia KS, Chew SK, Tan BY, Hughes K. Risk factors and incidence of coronary artery disease in Chinese, Malay and Asian Indians males: the Singapore Cardiovascular Cohort Study. Int J Epidemiol. 2001; 30(5): 983-988.

29. Heng DM, Lee J, Chew SK, Tan BY, Hughes $\mathrm{K}$, Chia KS. Incidence of ischaemic heart disease and stroke in Chinese, Malays and Indians in Singapore: Singapore cardiovascular cohort study. Ann Acad Med Singapore. 2000; 29(2): 231-236.

30. Amin AA, Nathan S, Evans AT, Attanasio S, Mukhopadhyay E, Metha V, et al. The effect of ethnicity on the relationship between premature coronary artery disease and traditional cardiac risk factors among uninsured young adults. Prev Cardiol. 2009; 12(3): 128-135. 